\title{
The Use of a Process-Oriented Approach to the Profit Formation of Enterprises Engaged in Innovative Activities
}

\author{
Hanna Doroshenko * [0000-0002-5535-8494], Oleksander Davydov [0000-0001-6764-2487] \\ V. N. Karazin Kharkiv National University, Kharkiv, Ukraine \\ *anyadoroshenkonew@gmail.com
}

\begin{abstract}
Modern economy with a high level of globalization and competition stimulates enterprises to establish new technology, business processes and tools of enterprise management, causes an increase in share of indirect costs in their full amount. Therefore, it is possible to manage profit through clear accounting record and indirect costs regulation. This is especially relevant for enterprises engaged in innovative activities, the organizational and managerial structure of which acquires the features of project oriented structure, which has the main characteristics of flexibility and lack of hierarchy. The purpose of this study is to reason the use of a modified process-oriented approach (TDABC) to the profit formation of innovative enterprises when making management decisions in the field of financial management. The analysis concluded that the use of the $\mathrm{ABC}$ approach to profit formation is appropriate when the group of costs is divided between processes attributed to different levels of the hierarchy, when costs are formed by different projects and can be attributed to a certain object, it is better to use TDABC approach. Accordingly, for enterprises that are engaged in innovative and search activities, and implementing one-time individual or small-batch orders, it is more appropriate to use the modified time-driven $\mathrm{ABC}$ approach (TDABC).
\end{abstract}

Keywords: profit, indirect costs, ABC approach, TDABC, innovative activities, processes.

\section{INTRODUCTION}

The formation of the economy of sustainable development is possible only with efficient enterprises functioning, the use of innovative methods in all management areas, the growth of public-private partnership, the ecologization of consciousness and more. However, all these changes demand proper sources of financing, the main source of which is the profit [1] of business entities. Accordingly, efficient profit management is not only the main task at the microeconomic level, but this activity aspect is also the foundation of overall development. However, the traditional approach to profit management, based on deficient informational base can lead to incorrect decisions that reduce the profit and perniciously affect the sustainability and enterprise growth potential. Globalization [1], intensification of economic connections, establishment of new business processes and tools of enterprise management lead to an increase in indirect costs. This is especially relevant for companies that implement innovative activities to meet their own strategic objectives as well as the ones which implement innovative activities to order.

The fact that domestic enterprises engaged in innovative activity are required to implement not only new technologies [3] and business processes, but also leading methods and tools of management, especially in the area of profit formation of business entities that organize their activity as project-oriented structures, makes the research relevant. In general, the concept of process-oriented approach - Activity-Based Costing (ABC) - was suggested by Cooper R. and Kaplan R.S. [4]. Numerous authors like Adkins T. [5], Namazi M. [6], Everaert P., Bruggeman W. [7], Medeiros H.D.S., Santana A.F.B [8] have tested the implementation of this approach to enterprises of different fields and areas. This approach is going through some modernization and is the subject to a significant part of research in both accounting and financial management, namely Pawłyszyn I. [9], Reynolds A., Fourie H. and Erasmus L. [10], Ruiz de Arbulo P., Fortuny J. [11] and others. However, the need to form an extensive approach to profit formation of enterprises 
engaged in innovative activities from management viewpoint taking into account the conditions of vagueness, which is intrinsic to numerous economies, including Ukraine, induces appropriate research.

\section{THE METHODOLOGICAL BASIS}

The methodological basis of the research are general scientific methods: analysis [12] and synthesis, comparison, grouping [13], abstraction and others. The theoretical basis are the studies on innovative activity, profit and cost management from the viewpoint of financial management. In order to achieve the set goal, the statistics of the Ministry of Finance and the Public Statistics Service of Ukraine were used.

\section{THE RESEARCH RESULTS}

Given the relevance of the research topic, the main goal is to reason the use of a modified process-oriented approach (TDABC) to the profit formation of innovative enterprises in management decisions in the field of financial management. Achieving this goal was realized by solving the following tasks: study of the state and place of enterprises engaged in innovative activity in the economy of Ukraine; analysis of the most common approaches to the profit formation and representation of their evolution; justification of practicability of using modified process-oriented approach for the enterprises with activity of innovative project-oriented character.

\section{DISCUSSION OF THE RESULTS}

In terms of globalization, the innovation of the enterprise is the main source of competitiveness, adherence of consumers and suppliers, the ability to attract additional resources in the financial market [14] and labor market. At the macro level, it is a source of economic growth, respect and trust in the country. Therefore, the assessment of innovative [15] development is given significant attention both at the enterprise level and by international agencies that form relevant ratings. As for Ukraine, in 2020 our country rose to 64th place in the Doing Business rating, ranked 45th among 131 countries in the report of Global Innovation Index 2020 [16].

However, the growth rate of innovative activity in Ukraine lags far behind neighboring countries, and to correct this situation, it is reasonable to pay more attention towards creating an advantageous business environment, the formation of a positive innovation image and the development of innovative activity.

Enterprises that actively implement innovations play a significant role in the economy and execute significant amounts of economic activity in modern conditions (Table 1). They are most efficiently developing in highand medium-tech areas of the economy [17], acting as effective forms of economic activity implementation.

Table 1. Costs and sources of the financing for innovation of industrial enterprises [18]

\begin{tabular}{|l|l|l|l|}
\hline Year & The share of innovatively active & The cost of innovation \\
\cline { 3 - 4 } & $\begin{array}{l}\text { enterprises in the total number of } \\
\text { industrial enterprises, \% }\end{array}$ & Total, UAH mln & $\begin{array}{l}\text { Financing from own } \\
\text { funds, } \%\end{array}$ \\
\hline 2012 & 17,4 & 11480,6 & 63,9 \\
\hline 2013 & 16,8 & 9562,6 & 72,9 \\
\hline 2014 & 16,1 & 7695,9 & 85,0 \\
\hline 2015 & 17,3 & 13813,7 & 97,2 \\
\hline 2016 & 18,9 & 23229,5 & 94,9 \\
\hline 2017 & 16,2 & 9117,5 & 84,5 \\
\hline 2018 & 16,4 & 12180,1 & 88,2 \\
\hline 2019 & 15,8 & 14220,9 & 87,7 \\
\hline
\end{tabular}

However, the data in Table 1 display a decrease in the share of enterprises engaged in innovative activity, a clear reason for this is the defect in financing. The main part of the innovations is financed from own funds, and given the disadvantageous geopolitical situation, the constant state of budget deficit on the background of the economic and COVID crisis, the ability of enterprises to self-finance is insignificant. Depreciation, one of the ways to finance the renewal of production capacity, has a low share (6-8\%) in the cost structure; profits as a source of financing have only become available over the last four to five years (Table 2). The data in Table 2 also display a gradual decrease in material costs (from $74.3 \%$ in 2012 to $71.4 \%$ in 2019) in total costs and an increase in the share of other costs, effective management of which can be considered as a source of increase in profits. The increase in the total cost of innovation indicates an awareness of their driving force in the development of enterprises, but not all business entities have the funds required for their implementation and the appropriate change in their organizational and managerial structure.

The growing attraction of innovative enterprises to the project-oriented structure is explained by the following arguments [19]:

- this structure allows integrating knowledge and inventions into development more efficiently; appropriately, to implement more technologically complex and intellectually rich projects; 
- project orientation is aimed at meeting the requirements of a particular customer, achieving specific results within the established terms of time and budget, i.e. to create a unique product;

- this way of organization allows obtaining the absolute effect in conditions of high variability, low standardization and a small number of complicated, contentually complex projects;

- organizational management structures of such enterprises are flat, most of the times, with a small number of management levels;

- horizontal integration within projects stimulates self-organization of employees and accelerates the adaptation of specialists of different professions, who have to work on one interdisciplinary project;

- the emphasis on the project activities contributes to the dynamic redistribution of resources from one project to another.

Hereby, a peculiar feature that forces managers of project-oriented innovative enterprises to actively seek new effective forms of management is that each of the projects may have its own system of planning, controlling, reporting, documentation. Therefore, the company should have an integrated profit management system that would clearly demarcate all costs between projects and would allow achieving a synergistic effect from the use of available resources and unused reserves.

Table 2. Costs of production (goods, services) and net profit of enterprises

\begin{tabular}{|c|c|c|c|c|c|c|c|c|}
\hline \multirow[t]{3}{*}{ Years } & \multirow{3}{*}{$\begin{array}{l}\text { Cost of } \\
\text { production } \\
\text { (goods and } \\
\text { services), } \\
\text { UAH mln }\end{array}$} & \multicolumn{6}{|c|}{ Out of these, the component costs } & \multirow{3}{*}{$\begin{array}{l}\text { Net profit } \\
\text { UAH mln }\end{array}$} \\
\hline & & \multicolumn{2}{|c|}{$\begin{array}{l}\text { Material costs and costs } \\
\text { of services used in } \\
\text { production }\end{array}$} & \multicolumn{2}{|c|}{ Depreciation } & \multicolumn{2}{|c|}{ Other costs } & \\
\hline & & UAH mln & $\begin{array}{l}\text { in } \% \text { to } \\
\text { the total }\end{array}$ & $\begin{array}{l}\text { UAH } \\
\text { mln }\end{array}$ & $\begin{array}{l}\text { in } \% \text { to } \\
\text { the total }\end{array}$ & UAH mln & $\begin{array}{l}\text { in } \% \text { to } \\
\text { the total }\end{array}$ & \\
\hline 2012 & 2077904,0 & 1544791,6 & 74,3 & 128330,5 & 6,2 & 30676,2 & 1,5 & 350672,7 \\
\hline 2013 & 1984065,5 & 1434694,0 & 72,3 & 139588,5 & 7,0 & 31559,8 & 1,6 & $-228397,4$ \\
\hline 2014 & 1952582,8 & 141980,9 & 72,7 & 138120,5 & 7,1 & 40228,4 & 2,1 & $-590066,9$ \\
\hline 2015 & 2434303,8 & 1805572,5 & 74,2 & 171416,2 & 7,0 & 64756,9 & 2,7 & $-373516,0$ \\
\hline 2016 & 2759942,9 & 2047986,8 & 74,2 & 224558,4 & 8,1 & 52607,6 & 1,9 & 29705,0 \\
\hline 2017 & 3525187,9 & 2644464,9 & 75,0 & 247062,4 & 7,0 & 63723,3 & 1,8 & 168752,8 \\
\hline 2018 & 4262963,9 & 3165253,1 & 74,3 & 287079,9 & 6,7 & 83520,8 & 2,0 & 288305,5 \\
\hline 2019 & 4675307,9 & 3336959,9 & 71,4 & 341595,3 & 7,3 & 95507,4 & 2,0 & 523779,0 \\
\hline
\end{tabular}

Compiled by the authors [18]

The evolution of approaches to the profit formation is closely connected with the development of economic relations. This process is significantly influenced by: change of activities; sources of financing; purposes of providing information; development of production capacity; management structure of the enterprise, which is presented in Table 3 .

As we can see, the development of approaches to the formation of reporting, cost accounting and profit formation leads to the need for a clear demarcation of costs. The time factor complicates the process of costs allocation. Variable costs are directly connected with the scope of production (raw materials, products, wages involved in the production of workers), fixed costs have little to do with the scope of production or it is not traced in the short term at all (rent and insurance payments, depreciation, calculated in a straight line and other). Administrative costs can also be divided into fixed and variable. However, when it comes to long-term planning, all costs are getting variable costs characteristics, but they are not strictly tied to the scope of the production output, and generally reflect the current tendency to increase or decrease. The reduction of the planning or analysis period allows most of the costs to be attributed to fixed costs. The division of costs into fixed and variable creates two ways of profit planning: by full costs (fixed part of production costs - a component of production costs) and by variables (constant part of production costs acts as a component of costs for the planning period, with fixed production costs taken into account as costs at the time of their occurrence, whereas variable production costs are included in the prime cost of finished products). The implementation of these methods is appropriate when the object of management is a direct resource and the share of overhead costs is insignificant and can only slightly affect the final result of the activity. 
Table 3. The main approaches to the profit formation: stages of development and characteristics

\begin{tabular}{|c|c|}
\hline Period & Characteristic \\
\hline $\begin{array}{l}\text { The XIV } \\
\text { century }\end{array}$ & $\begin{array}{l}\text { The first chaotic attempts to form reports on the activities results. The main purpose is to provide } \\
\text { information on the formation and distribution of profits between several partners-participants in the } \\
\text { trade operation. }\end{array}$ \\
\hline $\begin{array}{l}\text { The Mid-XIX } \\
\text { century }\end{array}$ & $\begin{array}{l}\text { The period of the industrial revolution. Economic indicators are being formed in accordance with } \\
\text { the specificity of particular industries. This information is essential primarily to assess the } \\
\text { effectiveness of the main internal processes. At this time, it is specialized activities and, } \\
\text { accordingly, the management of the main production process that allow working with the greatest } \\
\text { efficiency. The key criterion for capital investment was the expansion of the main activities (of } \\
\text { production). }\end{array}$ \\
\hline $\begin{array}{l}\text { The beginning } \\
\text { of the XX } \\
\text { century }\end{array}$ & $\begin{array}{l}\text { The period of development of vertically formed companies that combine several industries and } \\
\text { perform in several areas. Accordingly, to make management decisions it is necessary to have a set } \\
\text { of indicators that allow assessing the efficiency of each activity or each unit and compare them. It } \\
\text { is this period that is associated with the formation of widely used modern tools of financial analysis } \\
\text { and control: budgeting, transfer price formation, sales forecasting. }\end{array}$ \\
\hline $\begin{array}{l}\text { The } 30 \text { s of the } \\
\text { XX century }\end{array}$ & $\begin{array}{l}\text { Managers conclude that it is essential to separate the reporting, which is formed for different } \\
\text { purposes and, accordingly, to change the approaches to the organization of cost accounting for } \\
\text { various needs. }\end{array}$ \\
\hline $\begin{array}{l}\text { The } 60 \text { s of the } \\
\text { XX century }\end{array}$ & $\begin{array}{l}\text { Time of expeditious development of the stock market and active involvement of resources from } \\
\text { external sources. The financial result becomes the only measure of efficiency, and external } \\
\text { reporting (intended for creditors and investors) becomes the main one. The activity of managers is } \\
\text { assessed through the achievement of planned profits and the formation of external reporting with a } \\
\text { high indicator of capital profitability. Internal management was concentrated on break-even point } \\
\text { calculations and margin theories. }\end{array}$ \\
\hline $\begin{array}{l}\text { The beginning } \\
\text { of the XXI } \\
\text { century }\end{array}$ & $\begin{array}{l}\text { This is a period of globalization, integration, reduction of the product life cycle and increase in its } \\
\text { range, the implementation of a simultaneously large number of projects that are at different stages } \\
\text { of the life cycle. This causes a significant increase in indirect costs that are not directly connected } \\
\text { with profit changes, or such connections are difficult to establish. However, variable-cost profit } \\
\text { planning, which does not take into account indirect costs or distorts the understanding of planned } \\
\text { values with full costs, and provides a basis for making incorrect management decisions. In response } \\
\text { to this challenge, the ABC method and its modification, which takes into account the time factor, } \\
\text { are formed. }\end{array}$ \\
\hline
\end{tabular}

Compiled by the authors [20]

Modern production processes do not always meet the requirements [21], so it is advisable to consider other methods of profit planning, based on the relationship of resources used in different processes with the objects of costs, which forms the basis of the process-oriented approach (ABC approach). Examples of the processes can be: preparation of labs, equipment setup, organization of "field" research, production cycle management. This is especially relevant for projectoriented enterprises, since the objects of costs can be various tangible and intangible assets, customers, regulatory authorities and others [22]. This allows each project to form its own budget, in which the needs are distinctly linked to the final product, taking into account its scope, features, terms of delivery time to the customer.

The use of the $\mathrm{ABC}$ approach implies the presence of a large array of data for each process and its components. For instance, in order to calculate the target indicators for a two-year period for a company with 150 processes and more than half a million objects of costs, it is necessary to assess and store more than two billion pieces of information [21]. However, the idea itself is quite simple and logical. After all the costs are allocated to individual processes, or divided between several related processes, for each process the cost carrier is being selected (activity cost driver), pro rata, variables of which determine the degree of process implementation.

The unit of the cost carrier is determined by the ratio of the total cost of the process to the number of the corresponding implemented processes. The total amount of indirect costs transferred to the cost object is defined as the multiplication of the number of processes by the cost of the carrier.

The main reasoning behind this approach is the different degree of transfer of indirect costs to different objects. This allows making management decisions 
based on substantiated information about the defect or excess of certain indirect resources during the planning period.

The use of the ABC approach is based on the notion of cost hierarchy, which is presented in the work in its most modern and adapted version. The authors, Anderson Shannon W., Sedatole Karen L [23], note that not all types of costs are directly related to a unit of the production output, they may be connected with the level of support for the company's work or with the level of costs associated with the batch of products. Since it is a clearly ranked hierarchy, the costs are distinctly tied to the object of the corresponding level. At the same time, it is advisable to use the $\mathrm{ABC}$ approach in large, branched companies, as the cost of a model creation will be less than the benefit of its use. Given the small share of indirect costs, the enterprise does not get the economies of scale and the use of the ABC approach will not provide the expected result.

R. Kaplan is one of the founders of this approach who believed that the main issues in its use are: the need for clear demarcation and documentation of costs, high cost of creating and maintaining the model, the practicality of implementation only in large companies with diversified activities and repetitive processes, the impossibility of taking into account the effect of the use of reserves.

In order to remove some of these limitations, in 2007 R. Kaplan and S. Anderson developed and tested the modified ABC approach - Time-Driven Activity-Based Costing (TDABC) approach. The modification was presented by the introduced time factor, namely, the indicator - the cost of the time unit, which is calculated as the ratio of the cost of the resource and the time of the use of this resource. The second indicator of this approach is the duration of the process. Since any process can be measured by the length of time of its execution, whereas the costs are measured by the time of use of their carrier, the duration can be considered a universal meter. If in the classic $\mathrm{ABC}$ approach, the duration of processes is calculated as the share of process duration in total time, the TDABC is oriented to identifying the amount of time actually spent on a single operation (order reconciliation time, equipment preparation time). The presence of these indicators allows calculating the prime cost by multiplying the cost of the time unit by the duration of the process.

The advantage of the TDABC approach is the ability to calculate the requirement of the resource for a specific project, product unit, buyer. When using the ABC approach, the calculation of costs, needs per customer, project or production unit is done through the calculation of process costs, and then there is a transfer to the final objects. The limitation of the TDABC approach is the inability to distribute costs by hierarchy levels.
Due to the fact that the duration of the processes is used as a cost carrier, it is easier to make changes to the cost calculation model. Hence, when a new process arises, it is not necessary to list the prime cost of all cost carriers, it is enough to add a new variable to the existing model. The advantage of the use of the TDABC approach from the standpoint of reducing the complexity of the calculations and reducing the cost of the implementation is evidenced by the conclusions obtained by R. Hutchinson [24]. Using time-based accounting allows distributing the entire set of indirect costs through a single distribution base - the duration of the production cycle. In order to display the results of comparing the scope and limitations of the $\mathrm{ABC}$ approach with its modified version of TDABC, Table 4 is presented below.

Thereby, it can be stated that the use of the ABC approach is appropriate when the cost group is distributed between processes related to different levels of the hierarchy. When costs are formed by different projects and can be attributed to a particular object, it is better to use the TDABC approach.

After analyzing the nature and limitations of the TDABC and ABC approaches, following arguments can be presented - on the feasibility of their use for enterprises that are engaged in innovative activity and organize their work on a project principle. The implementation of one-time individual or small-batch orders increases the share and duration of preparation processes and enterprise management. The use of new resources in each project contributes to the increase in the production cycle, but the use of the "just in time" system allows managing time and reduce the delivery time and store the necessary resources. This increases the efficiency of the TDABC approach. Limitations on the impossibility of the demarcation of certain costs by levels of the hierarchy can be considered insignificant for project-oriented enterprises, which consider the formation of prime costs crucial from the standpoint of both profit management and the priority of allocating scarce resources. The simplicity in introducing additional variables into the model, as well as less complexity also indicate the advantage of this approach.

\section{CONCLUSIONS}

Innovative activity of enterprises is the engine of development at the micro- and macroeconomic level. Understanding this fact encourages enterprises to expand research, the implementation of new technologies, business processes and tools for enterprise management. The organizational and managerial structure of innovatively active enterprises tends to be projectoriented, facilitates the process of budgeting and redistribution of resources between projects, accelerates communication within the organization and with customers. 
Table 4. Requirements and limitations in the use of the TDABC and ABC approaches

\begin{tabular}{|l|l|l|}
\hline \multicolumn{1}{|c|}{$\begin{array}{c}\text { Requirements and limitations of } \\
\text { the approach }\end{array}$} & \multicolumn{1}{|c|}{ The ABC approach } & \multicolumn{1}{c|}{ The TDABC approach } \\
\hline Planning period & Month, quarter, year & Month, quarter, year, one project \\
\hline Prime cost planning period & $\begin{array}{l}\text { By the types of products, processes, } \\
\text { customers, levels of the hierarchy }\end{array}$ & By product units, projects, customers \\
\hline $\begin{array}{l}\text { Period of significant changes in } \\
\text { indirect costs }\end{array}$ & $\begin{array}{l}\text { Long production period and } \\
\text { planning period }\end{array}$ & Changes of a specific project \\
\hline $\begin{array}{l}\text { Period of calculation and providing } \\
\text { information }\end{array}$ & $\begin{array}{l}\text { The period exceeds the duration of } \\
\text { the production cycle, but is less } \\
\text { than the period of significant } \\
\text { changes in costs }\end{array}$ & $\begin{array}{l}\text { Corresponds to the periodicity of } \\
\text { project reporting }\end{array}$ \\
\hline Type of production & Large-scale or mass production & $\begin{array}{l}\text { Individual or small-scale productions, } \\
\text { one-time orders }\end{array}$ \\
\hline $\begin{array}{l}\text { Differences in the production } \\
\text { cycles of different products }\end{array}$ & Insignificant & Insignificant \\
\hline Product range & Insignificant & Insignificant \\
\hline $\begin{array}{l}\text { Changes in the model due to the } \\
\text { emergence of a new process }\end{array}$ & $\begin{array}{l}\text { Recalculation of the cost of all cost } \\
\text { carriers }\end{array}$ & Adding a new variable to the model \\
\hline
\end{tabular}

The development of industrial relations encourages the search for new approaches to profit formation management. Changing activities, sources of financing, purposes of providing information; the development of production capacity and management structure of the enterprise has led to the development of profit planning systems. The traditional planning system was formed in a period when a direct resource was of the main importance, and the share of indirect costs was insignificant and could not substantially affect the final result of the activity. Modern operating conditions, with a significant number of manufacturers organizing their activities on the principles of flexibility and client orientation, determine the increase in the share of indirect costs in their full amount. Therefore, it is possible to manage profits through clear accounting and regulation of indirect costs.

The analysis of the scientific literature has demonstrated the profitability of using $\mathrm{ABC}$ approach for enterprises with a high level of indirect costs, which allows linking used indirect resources for various processes with cost objects and, accordingly, with types of products, processes, hierarchy levels. This is especially relevant for project-oriented enterprises, since the cost objects can be various tangible and intangible assets, customers, regulatory authorities and others. This allows each project to form its own budget, in which the needs are distinctly linked to the final product, taking into account its scope, features, terms of delivery time to the customer. However, this approach has its limitations, which narrow the scope of its use. For enterprises engaged in innovative and exploration activities, implementing one-time individual or small-batch orders, it is more appropriate to use a modified time-driven $\mathrm{ABC}$ approach (TDABC).

\section{REFERENCES}

[1] Debaditya Barman and Nirmalya Chowdhury (2013), "Estimation of Possible Profit/ Loss of a New Movie Using "Natural Grouping" of Movie Genres", IJIEEB, vol. 5, no. 4, pp. 24-33, DOI: $10.5815 /$ ijieeb.2013.04.04

[2] Tanvir Ahmed (2016), "Cloud Computing a Solution for Globalization", International Journal of Education and Management Engineering, Vol.6, No.4, pp.30-38, DOI: 10.5815/ijeme.2016.04.04

[3] Xiao Xiong. Xu, Wan ting. Ye and Qiong. Shang (2011), "Using New Technologies to Support Collaborative Learning for College Students", IJEME, vol. 1, no. 3, pp. 73-78.

[4] Kaplan, R.S. and Cooper, R (1992), “Activitybased Systems: Measuring the Costs of Resource Usage", Accounting Horizons, September, pp. 113.

[5] Adkins, T. (2008), "Five Myths about Time-driven Activity-based Costing", Sascom Magazine, Second Quarter, pp. 1-5.

[6] Mohammad Namazi (2016), “Time-driven activitybased costing: Theory, applications and limitations", Iranian Journal of Management Studies, vol. 9 (3), pp. 457-482, available at: https://ijms.ut.ac.ir/article_57481_793361023886e 0c6698746124227687b.pdf

[7] Everaert, P. Bruggeman, W. Anderson, S.R. Levant, Y. and Sarens, G. (2008), "Cost modeling in logistics using time-driven ABC: Experiences from a wholesaler", International Journal of 
Physical Distribution \& Logistics Management, vol. $38 \quad$ (3), pp. 172-191, DOI: $10.1108 / 09600030810866977$

[8] Medeiros, H.D.S. Santana, A.F.B. and Guimarães, L.D.S. (2017), "The use of costing methods in lean manufacturing industries: a literature review", Gestão \& Produção, vol. 24 (2), pp. 395-406, DOI: $10.1590 / 0104-530 \times 2183-16$

[9] Pawłyszyn, I. (2017), "Time-driven activity based costing as a basis for undertaking lean activities", LogForum, vol. 13 (2), pp. 135-149, DOI: 10.17270/J.LOG.2017.2.2

[10] Reynolds, A. Fourie, H. and Erasmus, L. (2018), "A framework for time-driven activity-based costing implementation at small and medium enterprises", The Southern African Journal of Entrepreneurship and Small Business Management, vol. 10 (1), pp. 11-18, DOI: 10.4102/sajesbm.v10i1.194

[11] Ruiz de Arbulo, P. Fortuny, J. García, J. Díaz de Basurto, P. and Zarrabeitia, E. (2012), "Innovation in Cost Management. A Comparison Between Time-Driven Activity-Based Costing (TDABC) and Value Stream Costing (VSC) in an Auto-Parts Factory", Industrial Engineering: Innovative Networks, January, pp. 121-128, DOI: 10.1007/978-1-4471-2321-7_14

[12] Korystin, Oleksandr and Svyrydiuk, Nataliia (2021), "Activities of Illegal Weapons Criminal Component of Hybrid Threats", Proceedings of the International Conference on Economics, Law and Education Research (ELER 2021), vol. 170, 22 March, pp. 86-91, DOI: 10.2991/aebmr.k.210320.016

[13] Kotlyarevsky, Ya.V. Melnychenko, A.A. Ivanytska, O.M. Semenyuk, E.P. Kniaziev, S.I. and Melnikov, O.V. (2020), "New Economy: Evolution of Forms and Research Methodology", Sci. Innov., vol. 16, no. 1, pp. 15-30, DOI: $10.15407 /$ scine16.01.015.

[14] Tkachenko, Volodymyr Kwilinski, Aleksy Korystin, Oleksandr Svyrydiuk, Natalia and Tkachenko, Iryna (2019), “Assessment of information technologies influence on financial security of economy", Journal of security and sustainability issues, march, vol. 8, no. 3, pp. 375385, DOI: 10.9770/jssi.2019.8.3(7)
[15] Alovsat G. Aliyev (2019), "Development of Models of Manufacturing Processes of Innovative Products at Different Levels of Management", International Journal of Information Technology and Computer Science, vol. 11, no. 5, pp. 23-29, DOI: $10.5815 /$ ijitcs.2019.05.03

[16] Center for Humanitarian Technologies (2021), Ranking of countries in the world for ease of doing business, available at: https:/gtmarket.ru/ratings/doing-business

[17] Korystin, O.Ye. (2020), Chapter 4. State Legal Police of Scientific Prediction. Public administration in the digital economy, monograph, Tallinn, Scientific Center of Innovative Researches OU, DOI: 10.36690 PADE.

[18] State Statistics Service of Ukraine (2021), available at: http://www.ukrstat.gov.ua/

[19] Doroshenko, G. and Ovcharenko, V. (2021), "Management of the development of the organizational culture of corporations", Efektyvna ekonomika, vol. 4, DOI: 10.32702/2307-21052021.4.4

[20] Johnson, H.T. and Kaplan, R.S. (1987), "Relevance Lost: The Rise and Fall of Management Accounting", Management Accounting, Januar, pp. 22-30.

[21] Kaplan, R.S. and Anderson, S.R. (2004), "Timedriven activity-based costing", Harvard Business Review, vol. 82 (11).

[22] Santana, A. Afonso, P. Zanin, A. and Wernke, R. (2017), "Costing models for capacity optimization in Industry 4.0: Trade-off between used capacity and operational efficiency", Procedia Manufacturing, vol. 13, pp. 1183-1190 DOI: $10.1016 /$ j.promfg.2017.09.193

[23] Anderson, S.W. and Sedatole, K.L. (2013), "Evidence on the Cost Hierarchy: The Association between Resource Consumption and Production Activities", Journal of Management Accounting Research - American Accounting Association, vol. 25, pp. 119-141.

[24] Hutchinson, R. (2007), "Linking Manufacturing Strategy to Product Cost: Towards Time-Based Accounting", Management Accounting Quarterly, vol. 9 (1), pp. 31-42. 